\title{
INDÚSTRIA, DESENVOLVIMENTO ECONÔMICO E DESINDUSTRIALIZAÇÃO: SISTEMATIZANDO O DEBATE NO BRASIL
}

\author{
Wallace Marcelino Pereira \\ Doutorando do Programa de Pós-Graduação em Economia, Universidade Federal de Minas Gerais \\ (UFMG). \\ Endereço: CEDEPLAR - Centro de Desenvolvimento e Planejamento Regional da UFMG. Faculdade de \\ Ciências Econômicas - $3^{\circ}$ andar, sala 3132. Avenida Presidente Antônio Carlos, 6627 - Pampulha - Belo \\ Horizonte - MG \\ CEP: 31270 - 901 E-mail: wallacemp@yahoo.com.br
}

\section{Silvio Antônio Ferraz Cario}

Professor dos Cursos de Graduação em Economia e Relações Internacionais, Universidade Federal de Santa Catarina.

Endereço: CSE - Centro Socioeconômico da UFSC. Campus Universitário Reitor João David Ferreira Lima Trindade - Florianópolis - SC

CEP: 88040-900 E-mail: fecario@yahoo.com.br

\section{RESUMO}

A indústria de transformação é considerada o motor do crescimento, com reflexo sobre o desenvolvimento econômico dos países. Entretanto, desde meados da década de 80 o Brasil vem apresentando perda de participação da indústria no PIB, gerando intenso debate acadêmico sobre a possível existência de desindustrialização. Diante deste quadro, o objetivo deste artigo é sistematizar o tratamento analítico sobre a desindustrialização no Brasil, a partir da visão das principais escolas de pensamento existentes no país. O levantamento da literatura apontou a existência de quatro escolas de pensamento: UNICAMP, FGV-SP, PUC-RJ e UFRGS. O estudo aponta a existência de diferentes abordagens e estão presentes: fundamentos estruturalista da CEPAL, macroeconomia estruturalista do desenvolvimento, ortodoxia econômica e histórico-institucionalistaschumpeteriana. A distinção de análise sobre a desindustrialização contempla, por seu turno, propostas diferenciadas de solução, mostrando, assim, leque de opções rico em termos de política de econômica.

PALAVRAS CHAVE: Desindustrialização - Desenvolvimento econômico - Indústria no Brasil

\begin{abstract}
The manufaturing industry is considered the engine of growth, reflecting on the economic development of countries. However, since the mid-80 Brazil has had loss of industry in GDP, gerating intense academic dialogue about the possible existence of deindustrialization. Given this situation, the purpose of this article is to systematize the analytical treatment of deindustrialization in the Brazil from the perspective of the main scholls of thought within the country. The literarture review indicated the existence of four school of thought: UNICAMP, FGV-SP, PUC-RJ and UFRGS. The study points to the existence of diferentes approaches, are presente: CEPAL-estructuralist foundations, structuralist development macroeconomics, orthodoxy economic and historical
\end{abstract}


institutionalist-schumpeterian. The analysis of distinction on deindustrualization generates in turn, differentiated proposed solution, thus showing, range of rich options in terms of economiic policy.

KEY-WORD: Deindustrialization, Economic Development, Industry in Brazil

\section{INTRODUÇÃO}

A indústria de transformação é considerada o motor do crescimento, com reflexo sobre o desenvolvimento econômico dos países, por meio de seus retornos crescentes de escala, pela influência positiva sobre a taxa de produtividade da economia além de promover uma série de transformações estruturais capaz de superar a condição do subdesenvolvimento (KALDOR, 1966; THIRWALL, 2002; FURTADO, 1961). No plano internacional, por volta da década de 70 os países desenvolvidos começaram a apresentar queda sistemática da participação da indústria na composição do PIB. Diante desse comportamento, somente a partir da divulgação do relatório da United Nations Conference on Trade and Development (UNCTAD, 2003) deu-se início a um intenso, e profundo debate buscando não só conceituar o fenômeno, mas também entender a origem e as causas do processo de desindustrialização em curso nos países desenvolvidos. No esteio desse debate destacaram-se autores como Rowthorn e Ramaswany (1999); Palma (2005); Palma (2008); Tregenna (2008); Tregenna (2009); e Chang, (2010).

Nesse ínterim, a partir de meados da década de 80 a economia brasileira vem apresentando queda sistemática da participação da indústria na formação de seu Produto Interno Bruto (PIB), o que de forma idêntica tem chamado a atenção de diversos pesquisadores para a existência de um processo denominado desindustrialização relativa (COMIN, 2009; SILVA, 2012). Entretanto, a partir de 2005 quando da publicação do artigo "A maldição dos recursos naturais" por Bresser-Pereira, no Jornal Folha de São Paulo, o debate brasileiro sobre a desindustrialização se acirrou e ganhou contornos profundos, no ambiente acadêmico e nas esferas de governo e representações de classe.

Nesse sentindo, em 2015 completaram-se 10 anos de debate sobre o processo de desindustrialização brasileira, conformando ao longo desse tempo perspectivas bem definidas, mas pouco exploradas sobre as causas e as estratégias a serem adotadas para reverter essa trajetória de perda de participação da indústria na geração de riqueza nacional. Assim posto, o objetivo deste artigo é sistematizar o pensamento sobre a desindustrialização no Brasil a partir de Escolas de Pensamento, e evidenciar os avanços e as limitações nas interpretações desse comportamento da indústria nacional.

Neste sentido, o presente artigo encontra-se divido em 5 seções, sendo que nesta $1^{\mathrm{a}}$. seção faz-se a introdução; na $2^{\mathrm{a}}$. seção apresentam-se, de forma sintética, posições de autores em nível internacional sobre a desindustrialização e seus conceitos; na $3^{\text {a }}$. seção expõe-se a matriz interpretativa do processo de desindustrialização no Brasil a partir das principais escolas de ensino superior de economia do país; na $4^{\text {a }}$. seção traçam-se as principais proposições de política destas escolas de reversão do quadro de desindustrialização brasileiro em curso; e, por fim na $5^{\text {a }}$. seção faz-se a conclusão.

RE\&D Econ. e Desenv., Santa Maria, vol. 29, n.1, p. 587 - 609, jan. - jul. 2017 


\section{DEBATE INTERNACIONAL E OS CONCEITOS DE DESINDUSTRIALIZAÇÃO}

Por volta da década de 70 os países desenvolvidos começaram a apresentar queda sistemática da participação da indústria na composição do PIB. Entretanto, somente a partir da divulgação do relatório da United Nations Conference on Trade and Development (UNCTAD, 2003) deu-se início a um intenso debate buscando não só conceituar o fenômeno, mas também entender a origem e as causas do processo de desindustrialização em curso nos países desenvolvidos.

Nesse contexto, autores como Rowthorn e Ramaswany (1999); Rowthorn e Coutts, (2004); Palma, (2005) e Palma (2008), colocam que a desindustrialização pode ser entendida como um fenômeno marcado pela redução sistemática da participação do emprego industrial no emprego total de um determinado país. Em Palma (2005), a desindustrialização é entendida e definida em duas fases: a primeira, marcada pela queda em termos relativos do emprego industrial, e a segunda em termos absolutos com o setor de serviços passando a ser a fonte principal de absorção de mão de obra. Rowthorn e Ramaswany (1997) colocam o processo de desindustrialização como um movimento natural da trajetória de desenvolvimento econômico dos países centrais, não sendo portanto, um fenômeno negativo. Esse comportamento passa a ser considerado como um processo negativo, quando se observa a ocorrência de desindustrialização em países que não alcançaram estágios elevados de desenvolvimento.

Tregenna (2009) trata esse processo em que não só o emprego industrial, mas também o valor adicionado da indústria se reduzem em relação ao emprego total e do PIB. Nestes termos, "uma economia não se desindustrializa quando a produção industrial está estagnada ou em queda, mas quando o setor industrial perde importância como fonte geradora de empregos e de valor adicionado para uma determinada economia. Dessa forma, a simples expansão da produção industrial (em termos de quantum) não pode ser utilizada como "prova" da inexistência de desindustrialização." (OREIRO e FEIJO, 2010, pg. 221).

Assim, para se compreender e investigar o fenômeno da desindustrialização, necessita-se considerar adicionalmente duas dimensões, a saber: $1^{\mathrm{a}}$.) absoluta; e, $2^{\mathrm{a}}$.) relativa. A desindustrialização absoluta refere-se ao fechamento de unidades industriais, ou a redução do valor real da produção, bem como do valor absoluto do emprego na indústria de transformação total, setorial ou regional. A relativa, como aponta Feijó et al (2005) é entendida como a perda de importância de segmentos industriais relevantes, e a ruptura de elos em cadeias produtivas sem que o valor total da produção industrial se alterar. Entendese a desindustrialização relativa por meio de três categorias: 1) desindustrialização relativa por aumento do conteúdo importado; 2) desindustrialização relativa por aumento do coeficiente de importação; 3) desindustrialização relativa por aumento do gap tecnológico (SAMPAIO, 2015; FEIJÓ et al, 2005).

Diante desse panorama teórico, verificou-se a partir de meados da década de 80 , a queda sistemática da participação da indústria na formação de seu Produto Interno Bruto brasileiro. Esta ocorrência tem sido explicada mais como um processo de desindustrialização relativa que absoluta (COMIN, 2009; SILVA, 2012). Autores como Coutinho (1997), Carneiro (2008), Bresser-Pereira (2009) e Oreiro e Feijó (2010) têm demonstrado a existência de perda de importância relativa do setor industrial no PIB

RE\&D Econ. e Desenv., Santa Maria, vol. 29, n.1, p. 587 - 609, jan. - jul. 2017 
brasileiro, com perdas de elos da cadeia produtiva e redução da capacidade de dinamização da economia como um todo, como expressão da ocorrência de desindustrialização no Brasil.

\section{DEBATE NACIONAL SOBRE DESINDUSTRIALIZAÇÃO ${ }^{1}$}

A queda de participação da indústria no PIB, a partir de meados da década de 80 , chamou a atenção de diversos especialistas sobre a possibilidade de estar em curso no Brasil, um processo de desindustrialização. Apesar disso, raros estudos se dedicaram em sistematizar o pensamento sobre a desindustrialização brasileira em termos de escolas de pensamento, ou matriz interpretativa, e que se trata do objetivo deste trabalho.

Para tanto, o critério de classificação dos autores por Escolas de Pensamento foi realizado primeiramente, com base na filiação institucional ${ }^{2}$, e para os não filiados com base na trajetória de formação acadêmica e nas conclusões de seus trabalhos visando encontrar afinidades interpretativas sobre a desindustrialização. Assim sendo, temos a Escola de Campinas cuja interpretação é baseada na concepção Cepalina-Estruturalista, a Escola da Fundação Getúlio Vargas, cuja interpretação está calcada na Macroeconomia Estruturalista do Desenvolvimento, a Escola da PUC/RJ Casa das Garças, cuja linha interpretativa está baseada nos princípios da Economia Ortodoxa, e por fim, a Escola da UFRGS cujo entendimento sobre a desindustrialização está baseado na abordagem Histórico-Institucionalista-Shumpeteriano.

\subsection{ESCOLA DA UNICAMP - CEPALINA-ESTRUTURALISTA}

A abordagem da Escola de Campinas se enquadra no arcabouço heterodoxo de pensamento, fundamentada a partir do estruturalismo latino americano. Deste modo, Cano (2014) realiza uma análise da desindustrialização em curso nos principais países desenvolvidos, e em alguns subdesenvolvidos com ênfase no Brasil, e aponta que, enquanto o resto do mundo passava por um profundo processo de transformação e reestruturação industrial, a década de 80, para o Brasil, representou a cessão da trajetória de industrialização. Carneiro (2008) afirma que a década de 80 se mostra peculiar ao Brasil, onde o padrão de crescimento é marcado pelo lado da demanda (consumo e exportações líquidas) com alta volatilidade econômica.

No bojo deste processo o Estado perdeu a capacidade de induzir e coordenar investimentos empresariais privados, cujo resultado levou a deterioração não só da infraestrutura tradicional, como da infraestrutura em ciência e tecnologia (C\&T) (SARTI e HIRATUKA, 2011). Observou-se contínua perda, por parte das empresas públicas, da

\footnotetext{
${ }^{1}$ Importante ressaltar a existência de estudos que não afirmam existir em curso, processo de desindustrialização, como é o caso de Nassif (2006) e Torres e Kupfer (2011) que cautelosamente consideram a desindustrialização como uma ameaça real.

${ }^{2} \mathrm{O}$ termo filiação institucional refere-se a qual instituição/departamento de economia o professor pesquisador está lotado.
}

RE\&D Econ. e Desenv., Santa Maria, vol. 29, n.1, p. 587 - 609, jan. - jul. 2017 
capacidade de financiamento e o arrefecimento da capacitação tecnológica do setor privado (FERRAZ et al, 1995). Assim, ao longo da década de 80 "as empresas reagiram reorientando as estratégias de crescimento para o mercado externo, reduzindo os níveis de endividamento, aumentando o mark up, realizando investimentos localizados (exportadores) e de tipo defensivo (racionalização e modernização da capacidade existente), em lugar dos investimentos em expansão ou instalação de novas unidades de produção." (LAPLANE e SARTI, 2006, pg. 275).

Na década de 90 a diretriz econômica foi o estímulo à concorrência como elemento capaz de promover a rápida transformação da estrutura produtiva, por meio da modernização de plantas industriais em razão do barateamento dos bens de capital, e redução da verticalização, na direção de uma alocação de recursos mais afinada com as vantagens comparativas (CARNEIRO, 2002; CARNEIRO, 2008). Para Carneiro (2002), no Brasil o resultado mais marcante da fase neoliberal foi a desnacionalização da economia, capitaneada pelo processo de privatização, em que empresas foram compradas e vendidas em seguida, demonstrando caráter especulativo. As empresas "reagiram à abertura e à política econômica aprofundando a especialização e a racionalização da capacidade produtiva, com forte redução de emprego. $\mathrm{O}$ ajuste foi realizado com baixo investimento, introduzindo mudanças organizacionais e abandonando linhas de produtos. As empresas nacionais procuraram parceiros estrangeiros para estabelecer acordos de complementação de linhas de produtos importados e de prestação de serviços no mercado doméstico" (LAPLANE e SARTI, 2006, pg. 275).

Os resultados para a indústria durante essa fase de abertura comercial foi a defasagem tecnológica em razão da não incorporação dos setores de ponta do novo paradigma tecnológico, a ampliação do coeficiente importado para a indústria em geral e, em particular, para o segmento produtor de bens de capital, o que levou a uma reestruturação da indústria com uma parcial atualização tecnológica (CARNEIRO, 2008). O Brasil, em fins da década de 90 e início de 2000, com a obsolescência da capacidade operacional deparou com desemprego estrutural e desigualdades sociais, que levaram a contração do mercado, com baixos níveis de consumo per capita da grande parte dos produtos industriais (FERRAZ et al, 1995). Além disso, todas as atividades e rotinas cujo aumento da competitividade não pudesse ser obtido de imediato foram abandonadas pelas empresas (CARNEIRO, 2008; LAPLANE E SARTI, 2006). A estrutura industrial passou a ser marcada pela tendência à impossibilidade em incorporar a nova onda tecnológica, marcada pelo uso de material eletrônico e de comunicação, ao passo que as indústrias baseadas em recursos minerais ganharam mais espaço (CARNEIRO, 2008).

Assim, o perfil da produção industrial brasileira passou a sofrer modificações no sentido da especialização em atividades intensivas em recursos naturais, abandono da busca por inovações e com menor exposição à concorrência externa, levando a um processo chamado de "especialização regressiva" da produção industrial brasileira (COUTINHO, 1997; GONÇALVES, 2001; LAPLANE E SARTI, 2006; PRATES, 2006). Enquanto isso, o mundo e principalmente a Ásia, por meio da China, engendrou um processo de desenvolvimento econômico que aproveitou o deslocamento de manufaturas da Europa e Estados Unidos para alavancar seu desenvolvimento industrial que começou por etapas mais simples, até as etapas mais complexas por meio de parcerias entre capital estrangeiro e capital nacional privado ou estatal (SARTI e HIRATUKA, 2011).

RE\&D Econ. e Desenv., Santa Maria, vol. 29, n.1, p. 587 - 609, jan. - jul. 2017 
O resultado decorre de longo processo de deterioração da estrutura industrial nacional, que Cano $(2011 ; 2012 ; 2014)$ se deve as razões: $\left.1^{\text {a }}\right)$ o câmbio excessivamente valorizado que faz com que a indústria nacional perca competitividade internacional perante as indústrias de outros países; $2^{\mathrm{a}}$ ) a abertura econômica desregrada, iniciada no governo Sarney em 1989, ampliada no governo Collor em 1990 e aprofundada no governo Fernando Henrique Cardoso a partir de 1994, foi responsável no desgaste da indústria nacional em relação à concorrência internacional; $3^{\mathrm{a}}$ ) a taxa de juros elevada do país, que faz com que o empresário brasileiro compare opções de investimento financeiro com as taxas de lucro advindas da produção, conduziu o empresariado nacional a investir produtivamente como última opção; e, $4^{\mathrm{a}}$ ) o investimento direto estrangeiro, que quando desmembrado revela que a alocação setorial do investimento está fortemente concentrada em serviços - financeiro, imobiliário, por ex.

Assim sendo, mantendo-se o atual quadro pode-se observar, conforme expõe Coutinho (1997) a tendência à desindustrialização avançar em três dimensões: i) redução do valor-agregado no país em todas as cadeias industriais complexas; ii) perda de espaços da oferta doméstica de bens finais pela ocupação de parte do mercado por produtos importados; e iii) em alguns casos, a supressão e substituição da produção por importações.

Por fim, importante ressaltar o estudo de Campolina Diniz e Campolina (2007) ${ }^{3}$ que concluem estar o Brasil em processo de desindustrialização, mas atentam para a dimensão regional desse processo ao considerar que a Região Metropolitana de São Paulo (RMSP) precisa ser avaliada em outra perspectiva, em função desta, apresentar na realidade um processo de reestruturação produtiva na medida em que a expansão do setor de serviços confere dinâmica diferenciada para esta região.

Figura 1: Escola da UNICAMP - Cepalina-Estruturalista.

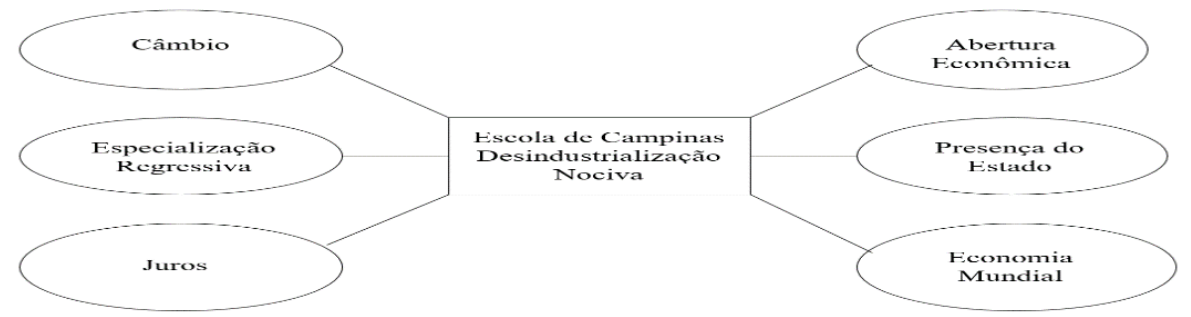

Fonte: elaboração própria

Em síntese, a Escola de Campinas é marcada pelo pensamento crítico em relação às políticas econômicas vigentes, bem como nas análises de conjuntura econômica que pode ser expresso pela Figura 1. O lado direito do diagrama corresponde aos elementos externos e conjunturais, sendo eles o grau de abertura econômica, fruto do período de auge do pensamento neoliberal que marcou os fins da década de 80 e toda década de 90 . A questão da presença do Estado é analisada de duas formas a saber: 1) sobre a ótica da abertura e liberalização econômica que propunha o Estado mínimo, e que por consequência levou, conforme propõe a Escola de Campinas, à desorganização dos incentivos à

\footnotetext{
${ }^{3} \mathrm{O}$ termo filiação institucional refere-se a qual instituição/departamento de economia o professor pesquisador está lotado.
}

RE\&D Econ. e Desenv., Santa Maria, vol. 29, n.1, p. 587 - 609, jan. - jul. 2017 
industrialização e perda da capacidade de investimento em infraestrutura e desenvolvimento C\&T; e 2) a necessidade de retomada do Estado como indutor do desenvolvimento por meio do fomento, e coordenação de política de desenvolvimento industrial. Por fim, o elemento relacionado à economia mundial diz respeito tanto ao boom de commodities, após 2008 como elementos que permitiram gerar receitas capazes de cobrir o balanço de pagamento no período de alta das importações e promover uma rearticulação dos países avançados e em desenvolvimento, em especial a China, no sentido de ampliar a competitividade dos manufaturados em escala global.

\subsection{ESCOLA DA FUNDAÇÃO GETÚLIO VARGAS - SP - MACROECONOMIA ESTRUTURALISTA DO DESENVOLVIMENTO}

Os estudos relacionados à desindustrialização se encontram dentro do arcabouço teórico denominado Macroeconomia Estruturalista do Desenvolvimento desenvolvido pela Fundação Getúlio Vargas. A Macroeconomia Estruturalista do Desenvolvimento tem em seu núcleo duas dimensões básicas: a tendência dos salários crescerem menos do que a produtividade, e a tendência a sobre apreciação cíclica da taxa de câmbio (BRESSERPEREIRA e GALA, 2010; BRESSER-PEREIRA, 2011). Nesta segunda dimensão, o problema da desindustrialização tem sido analisado com base em dois pontos, a saber: o problema da doença holandesa, e indiretamente o problema do crescimento com poupança externa (BRESSER-PEREIRA; NAKANO, 2003; BRESSER PEREIRA; GALA, 2010).

No que tange ao crescimento com poupança externa, Bresser Pereira (2013) aponta que a desindustrialização brasileira, e o período de baixo crescimento começaram nos anos 1980, como resultado em parte da crise financeira/dívida externa, consequência esta, da política de crescimento com poupança externa que se expressa por meio de déficits em conta corrente, sobre apreciação cambial e endividamento externo. No tange ao problema da "doença holandesa", Bresser Pereira e Marconi (2008) colocam que a sua origem reside a partir dos anos 90, quando o Brasil optou por dar início ao processo de abertura comercial e financeira, permitindo a eliminação dos mecanismos ${ }^{4}$ que outrora neutralizam a referida doença desde a década de 30.

O tema ganhou contornos mais consistentes no artigo intitulado "Maldição dos recursos naturais" no qual Bresser Pereira (2005), argumenta que a apreciação artificial do câmbio advinha da condição estrutural da economia brasileira ligada à maldição dos recursos naturais. Em outros termos, a abundância de recursos naturais, implica na produção de commodities a um custo muito baixo, levando ao surgimento de rendas ricardianas, com forte atração de recursos externos, e resultando em uma "doença holandesa" que inviabiliza investimentos produtivos em setores de bens comercializáveis de tecnologia elevada (BRESSER PEREIRA, 2010; BRESSER PEREIRA e MARCONI, 2009; BRESSER-PEREIRA et al, 2009a).

Nestes termos, a "doença holandesa" é uma grave falha de mercado porque implica na coexistência de duas taxas de câmbio de equilíbrio: a taxa de câmbio de equilíbrio corrente, que equilibra intertemporalmente a conta corrente do país, e a taxa de câmbio de equilíbrio industrial, que é a taxa que viabilizaria a produção no país de outros bens

\footnotetext{
${ }^{4}$ Os referidos mecanismos são a política de controles tarifários, alfandegários e cambiais, que taxava a receita de exportações de commodities primárias e desestimulava a importação de produtos manufaturados, resultando no incentivo à sua produção interna.
}

RE\&D Econ. e Desenv., Santa Maria, vol. 29, n.1, p. 587 - 609, jan. - jul. 2017 
comercializáveis distintos dos que dão origem à "doença holandesa" (BRESSER PEREIRA e MARCONI 2008; BRESSER-PEREIRA ET AL, 2009a). Em outras palavras, "a desindustrialização causada pela "doença holandesa" está associada a déficits comerciais crescentes da indústria e superávits comerciais (crescentes) no setor não industrial." (OREIRO e FEIJÓ, 2010, pg. 223).

Como o Brasil tem apresentado uma tendência à sobrevalorização da taxa de câmbio que é mais compatível com o equilíbrio em conta corrente, do que com competitividade industrial, a "doença holandesa" se manifesta por meio do processo de desindustrialização mesmo com a conta corrente equilibrada ${ }^{5}$ (BRESSER PEREIRA, 2010). Nesse quadro, Soares et al (2013) replicam a metodologia de Rowthorn e Ramaswany (1999) para ao anos 1996 a 2008, visando identificar se os determinantes da desindustrialização podem ser encontrados em fatores internos ou externos. Apontam que o país depara com desindustrialização relativa, e que o período de maior intensidade foi quando as economias brasileira e a mundial passaram por crises. Corrobora a visão de Tregenna (2009) de que as principais fontes de desindustrialização estão ligadas a quedas dos preços relativos e redução da taxa de investimento.

Nassif et al (2013) por meio de testes econométricos para o período de 1970 a 2010, constataram a existência de desindustrialização precoce com processo de falling behind comparativamente aos países desenvolvidos e emergentes. Os autores, apontam que na última década a elasticidade renda da demanda por importações foi maior que a elasticidade renda da demanda por exportações, de modo que, a restrição no balanço de pagamentos passou a ser fator impeditivo à trajetória de crescimento de longo prazo. Na mesma linha de argumentação, Sonaglio (2013), aponta que entre 1996 e 2008 observou-se tendência à reprimarização da pauta de exportações, revelando relação estreita entre o câmbio e a dinâmica industrial, de modo que, movimentos no sentido da apreciação cambial implicam em redução das exportações, sugerindo que a indústria nacional compete internacionalmente via preço.

Do ponto de vista doméstico, da Rocha Loures et al (2006) avaliando a desindustrialização em uma perspectiva de política econômica, aponta que desde 1994 a política econômica pode ser definida como uma política de "servidão consentida", na medida em que se trata de uma combinação perversa de juros altos, taxa de câmbio apreciada, tributação exorbitante, e redução do gasto público em infraestrutura. Diante disso, e mais especificamente no que tange ao comportamento da política monetária com seu caráter recessivo, por meio de taxas nominais e reais de juros elevadas por parte do Banco Central, tem-se contribuído para desacelerar o ritmo de crescimento da produtividade da indústria, e por consequência, a competitividade das exportações manufatureiras, dada a queda do ritmo da produção industrial ${ }^{6}$ (DA ROCHA LOURES ET AL, 2006).

A síntese desta escola de pensamento pode ser encontrada em Bresser-Pereira e Marconi (2008): a) há uma apreciação da taxa de câmbio, em função do aumento das

\footnotetext{
${ }^{5}$ Cabe ressaltar que a gravidade da "doença holandesa" se mede pela diferença existente no país entre estas duas taxas de câmbio. BRESSER PEREIRA e MARCONI (2008).

${ }^{6}$ A hipótese do autor é a existência de um círculo vicioso onde o aumento da taxa de juros para coibir pressões inflacionárias gera quedas no ritmo de crescimento da produção industrial, da produtividade e do investimento da indústria, o que perpetua a razão pela qual o Banco Central necessita manter as taxas de juros elevadas (DA ROCHA LOURES, OREIRO E PASSOS, 2006).
}

RE\&D Econ. e Desenv., Santa Maria, vol. 29, n.1, p. 587 - 609, jan. - jul. 2017 
exportações; b) a balança comercial das commodities, ou produtos que geram a "doença holandesa", evoluiu positivamente após 1992, enquanto a dos manufaturados sofreu uma retração no mesmo período; c) a balança comercial de commodities evoluiu de forma desassociada da taxa de câmbio, evidenciando que outros fatores influem no comportamento das vendas e compras externas destes produtos, enquanto a evolução da balança comercial dos manufaturados é fortemente vinculada à da taxa de câmbio, indicando que este setor depende de tal taxa para apresentar resultados positivos no comércio externo; d) os preços e quantum das exportações de commodities cresceram mais que os dos manufaturados; e) houve um aumento da participação das commodities no valor adicionado total; e, d) ocorrência de substancial diminuição da participação dos manufaturados comercializáveis.

\section{Figura 2: Escola da Fundação Getúlio Vargas - Macroeconomia Estruturalista do Desenvolvimento}

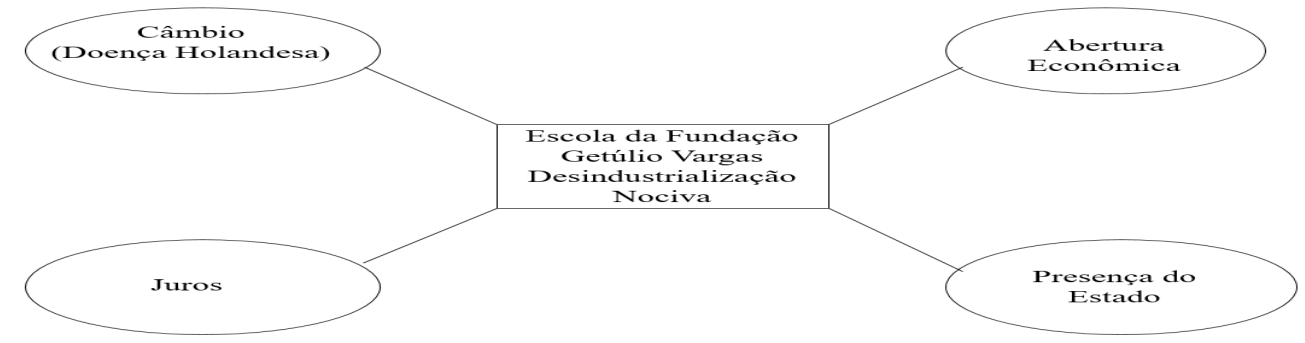

Fonte: Elaboração própria

Assim posto, a Figura 2 esquematiza os principais pontos que sustentam os argumentos da Escola da Fundação Getúlio Vargas. No lado direito, são os elementos, externos que corroboram a atual situação da economia brasileira, e no lado esquerdo correspondem aos fatores internos a estrutura política e econômica do Brasil. A questão da presença do Estado está vinculada a questão da abertura econômica, mas sua importância reside na questão da política cambial e na condução dos juros. Ainda que de forma não explicita, o Estado é chamado a coordenar a política econômica tendo como mote principal a indústria, como motor do crescimento. Nesse sentido, estabelece o vínculo necessário para compreender o lugar da política econômica (fiscal, cambial e creditícia) nas leis de Kaldor (1966): seja, por meio da política fiscal e creditícia de incentivo a demanda, ampliando a produção e da produtividade, seja por meio da política cambial visando mitigar os efeitos sobre o balanço de pagamentos.

\subsection{ESCOLA DA PUC-RJ/CASA DAS GARÇAS - ABORDAGEM ORTODOXA DA ECONOMIA}

O debate acerca da existência ou não de desindustrialização no Brasil também é composto pela abordagem ortodoxa. As contribuições desta escola de pensamento têm sido formuladas pelos estudiosos da PUC - RJ / Casa das Garças, e cujo arcabouço está estruturado basicamente em quatro dimensões sobre a desindustrialização brasileira, a

RE\&D Econ. e Desenv., Santa Maria, vol. 29, n.1, p. 587 - 609, jan. - jul. 2017 
saber: a dimensão internacional, o problema das mudanças metodológicas na coleta de dados estatísticos, a fase da sobreindustrialização brasileira, e o problema da poupança interna ou doméstica.

A dimensão internacional é abordada pela ótica dos preços/eficiência na produção das commodities, o volume de entrada de capitais, o fraco desempenho da indústria em nível global e o efeito da integração da China e Índia à economia mundial (PUGA, 2007; BONELLI, PESSOA e MATOS, 2013). Para Malan (2013) aponta que o debate sobre a desindustrialização brasileira requer uma análise que possibilite separar o que é relevante, do que não é mais passível de discussão. Afirma que a hipótese de uma tendência de longo prazo ao declínio dos termos de troca entre produtos primários e produtos manufaturados e a "doença holandesa" são questões superadas no debate. Primeiro, os produtos agropecuários incorporaram avanços tecnológicos e inovativos que lhes garantiram um nível de produtividade elevado, cujos preços podem ser superiores aos dos produtos manufaturados (Lazzarini, Jank e Inoue, 2013); e segundo, o Brasil possui produtos exportáveis diversificados que apresentam conteúdo de produtos importados por unidade, ampliando a produção a despeito do coeficiente de penetração da indústria brasileira estar baixo da média mundial (PUGA, 2007; MALAN, 2013).

Na mesma linha, Fishlow (2013) sinaliza que os ganhos de produtividade não se limitam apenas ao setor industrial, mas sim, de uma integração dos setores agrícola, mineral, e de petróleo, de manufaturas e de serviços. Observa que as atuais exportações de commodities não são como a dependência histórica do café, mas sua origem reside atualmente na melhoria da eficiência deste setor. As commodities não parecem configurar uma maldição para a economia (Lazzarini, Jank e Inoue, 2013). Para Bonelli, Pessoa e Matos (2013) apontam que o fenômeno de perda de peso da indústria na economia inclui três dimensões inter-relacionadas: caráter cíclico do desempenho da indústria em todo o mundo, a entrada da China e da Índia que tem provocado um desequilíbrio no quadro das vantagens comparativas globais com impacto nas indústrias de diversos países, e a tendência natural de perda de peso da indústria no mundo, como resultado de mudança nos padrões de consumo advindos do crescimento econômico.

De fato, conforme relatório da Unido (2013) a China passou de 19,9\% em 1992, para 50\% em 2012 no que tange ao acréscimo no valor adicionado industrial, enquanto o Brasil no mesmo período regride de $10,5 \%$ para $4,9 \%$ respectivamente. ${ }^{7}$ Em virtude dessa nova configuração, diversos países têm se preocupado com o desempenho da indústria, principalmente após a crise de 2008, cujo desempenho em 2011 ainda corresponde ao de três anos atrás (BONELLI e PINHEIRO; 2012).

Para, além disso, Bacha (2013) expõe que uma das razões para a queda da participação da indústria de transformação no PIB brasileiro, pode ser consequência da bonança externa de que o Brasil desfrutou no período de 2005 a 2011. A indústria padeceu da chamada "doença holandesa" causada pela valorização da taxa de câmbio real e impulsionada pela melhoria das relações de troca, e o aumento da transferência de recursos financeiros do exterior. Em linha, Pastore, Gazzano e Pinotti (2013) colocam que a letargia industrial, a partir de 2010, foi agravada pela forma como o governo reagiu a crise. Em condição de quase pleno emprego a elevação dos salários reais acima da produtividade

\footnotetext{
${ }^{7}$ Para mais detalhes ver: Industrial Development Report 2013. Pg. 172.
}

RE\&D Econ. e Desenv., Santa Maria, vol. 29, n.1, p. 587 - 609, jan. - jul. 2017 
média do trabalho e a expansão do crédito levaram a um aumento do consumo. Isto ampliou da absorção, com deslocamento para o aumento das importações liquidas, cujo resultado nas contas externas não foi deficitário em razão dos preços favoráveis das commodities advindos da bonança externa.

Por sua vez, a bonança externa ajudou a promover o deslocamento de mão de obra do setor industrial para o setor de setor de serviços, contribuindo assim, para o processo de desindustrialização (BACHA, 2013). Entretanto, apesar da gravidade do processo em curso, Bacha e Bonelli (2005) concluem que a desindustrialização brasileira se limita ao período pós década de 90 , fruto de fatores exógenos como a crise mexicana e russa, e que preocupações referentes a esse processo só deveriam ocorrer, se a taxa de crescimento da produção industrial fosse persistentemente baixa no médio prazo.

No que se refere à questão metodológica, Barros e Pereira (2008) negam a forma como tem sido empregado o conceito de desindustrialização e afirmam que a forma de análise mais adequada ao caso brasileiro, é considerar a existência de uma reestruturação produtiva. Os autores consideram que o erro se deve à forma como se analisa o setor de serviços, que segundo a classificação CNAE, congrega desde serviços cujo foco é o atendimento às necessidades pessoais, quanto os serviços vinculados à indústria. Corroborando, Bonelli e Pessoa (2013) apontam que ao se fazer uma análise mais detalhada da trajetória da participação da Indústria de Transformação no PIB de 1947 a 2008, observa-se que as grandes quedas da fatia do produto industrial estão relacionadas aos períodos de mudanças de metodologia no cálculo do PIB.

Os autores argumentam que quando se analisa a evolução a preços correntes, como é o caso da formação bruta de capital fixo, nota-se que o peso da indústria diminuiu desde meados da década de 1980, mas quando a análise é feita a preços constantes, a queda além de ser bem menor, começa uma década antes. Os cálculos realizados a preços constantes, parecem ser os mais adequados para se avaliar o comportamento da indústria de transformação brasileira (Bonelli e Pessoa, 2010; Binelli e Pessoa (2013); Pastore, Gazzano e Pinotti, 2013). E, Bonelli, Pessoa e Matos, (2013) ressaltam que as mudanças metodológicas das fontes dos dados podem implicar no risco de análises errôneas. Apontam que a forma mais correta de avaliar a existência de desindustrialização é pela medição a preços constantes, o que tem evidenciado que as quedas de participação da indústria no PIB sugerem ser menores do que se pensava.

A questão da sobreindustrialização brasileira tem sido ponto de grande crítica aos ortodoxos. Para Bonelli e Pessoa (2010) e Bonelli, Pessoa e Matos (2013) o processo de desindustrialização brasileira é natural, e se enquadra no movimento global dos países desenvolvidos no sentido de convergir para o nível ideal. Avaliando 170 países em um período de 40 anos, constataram que o Brasil sofre de "doença soviética", entendida como uma indústria acima do padrão internacional quando se considera o grau de desenvolvimento, população, tecnologia, dotação de recursos naturais. Nesse sentido, após a liberalização econômica, a participação da indústria no PIB volta ao ponto de normalidade condizente com a condição brasileira, implicando que a desindustrialização não seja um problema para a economia brasileira, mas talvez até mesmo um processo desejável (BERRIEL, BONOMO E CARVALHO (2013); BONELLI, PESSOA E MATOS, 2013; BONELLI E PESSOA, 2010).

Por fim, o problema da poupança doméstica é aventado por Bacha (2005) e Bonelli e Pessoa (2010) cuja expressão se dá por meio do câmbio valorizado, e se manifesta por

RE\&D Econ. e Desenv., Santa Maria, vol. 29, n.1, p. 587 - 609, jan. - jul. 2017 
meio do processo de desindustrialização. Em Bonelli e Pessoa (2010) encontramos um argumento hipotético e esquemático em que por meio da existência de dois bens, comercializáveis e domésticos, e com uma política econômica de fomento da elevação da poupança doméstica, observar-se uma queda da demanda por ambos os bens. Deste modo, o excesso de oferta pelo bem doméstico, somente poderá ser eliminado por meio de uma redução do preço relativo do próprio bem doméstico em unidades de bens comercializáveis. Como resultado, ocorre uma desvalorização cambial que reverteria o processo de desindustrialização brasileira.

Entretanto, Pastore, Gazzano e Pinotti, (2013) apontam que a mudança em 2012 do regime cambial para um regime de bandas estreitas de flutuação, como forma de recomposição da competitividade industrial, por meio do câmbio sem a adoção de políticas de austeridade fiscal e monetária para garantir a transmissão da depreciação do câmbio nominal para o câmbio real gerou um processo inflacionário e o desequilíbrio na economia. Diante deste quadro e do ciclo de queda dos preços das commodities, o governo central põe em marcha uma série de políticas anticíclicas que estimulam o consumo das famílias, e por consequência, a queda da poupança interna e o aumento do custo unitário do trabalho, cujo impacto é a redução dos lucros retidos das empresas produtoras de bens tradables, e a carência de investimentos estimulando o processo de desindustrialização (PASTORE, GAZZANO E PINOTTI, 2013).

\section{Figura 3: Escola da PUC-RJ/Casa das Garças - Abordagem Ortodoxa da Economia}

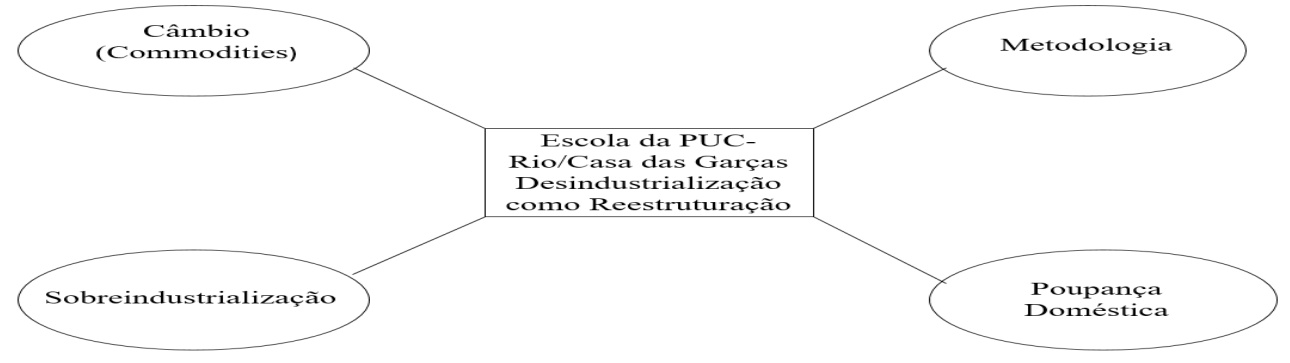

Fonte: Elaboração própria.

Desta forma, a Figura 3, sintetiza o pensamento ortodoxo capitaneado pela PUCRio/Casa das Garças sobre o processo de desindustrialização em curso na economia brasileira. Em síntese, como pode ser observado pelo diagrama 3, o pensamento ortodoxo capitaneado pela PUC-Rio/Casa das Garças considera a desindustrialização como não problemático à economia nacional, no sentido de que a desindustrialização é natural, e faz parte da dinâmica de ajustamento global das economias em todo o mundo. A presença do Estado como indutor do desenvolvimento provoca uma série de distúrbios que agudizam os desequilíbrios provocados pela sua própria atuação. Integrar o Brasil às cadeias globais é essencial dado que fechar a economia como forma de proteção à indústria é um erro de política econômica que acelera a deterioração da indústria e inviabiliza a adoção de novas formas produtivas.

\subsection{ESCOLA DA UFRGS - HISTÓRICO-INSTITUCIONALISTA- SHUMPETERIANA}

RE\&D Econ. e Desenv., Santa Maria, vol. 29, n.1, p. 587 - 609, jan. - jul. 2017 
Nesta escola, reúnem-se os estudiosos que procuraram investigar a desindustrialização brasileira por meio de abordagens teóricas não tradicionais do escopo de análise econômico. Considerando elementos históricos e teórico econômicos, Arend (2009) investiga a trajetória de industrialização brasileira pós-1955 a partir de uma abordagem de economia evolucionária. Contando com elementos neoshumpeterianos, mas balizados pelas propostas de path dependence e efeito locked in, o autor aponta que o crescimento econômico brasileiro foi resultado, grande parte, do movimento de expansão do capital internacional característico da fase de maturidade da quarta revolução tecnológica do que fatores endógenos à economia brasileira. No esteio desse processo, a reduzida participação dos setores difusores de tecnologia da quinta revolução tecnológica na indústria de transformação, bem como a dependência por transferências tecnológicas, modelo este adotado antes de 1980, exerceu influência na debilidade de mudança industrial e no insuficiente dinamismo econômico do Brasil, configurando portanto um processo de falling behind nos últimos 25 anos (AREND, 2009; AREND e FONSECA, 2012).

Mais recentemente, Arend (2014) analisando a posição do Brasil no processo de transformação industrial mundial, aponta que a estrutura industrial brasileira vem apresentando relativa rigidez e heterogeneidade com tendência ao aprofundamento de sua especialização produtiva em detrimento de setores mais dinâmicos. Tal quadro se expressa não apenas na conjuntura atual, mas desde a década de 1980 em relação ao mundo, à América Latina, e demais economias desenvolvidas e em desenvolvimento. O período pós 2008 registra a presença da China na América Latina e tem levado à integração deste continente no comércio internacional como produtor de commodities. Ao mesmo tempo, tem imposto aos países latinos com indústrias de transformação mais robustas e diversificadas, uma concorrência agressiva com perda de dinamismo nas exportações de seus produtos manufaturados (CUNHA, LELIS e BICHARA, 2012; CUNHA, LELIS E FLIGENSPAN 2013).

Feijó e Oliveira (2013) também apontam que as dificuldades na indústria brasileira têm suas raízes no processo de desenvolvimento dos últimos vinte anos, marcada pela direção no sentido de diminuir o peso relativo de setores intensivos em tecnologia. Em decorrência disso pode-se observar duas consequências, a saber: 1) em função de uma manufatura menos densa em termos de elos da cadeia produtivas faz com que parte dos estímulos de demanda agregada sejam transferidos para o exterior, dado que a oferta é atendida por bens e serviços importados; e, 2) enfraquecimento das ligações dos setores industriais com demais setores da economia. Os dois pontos citados trazem nas entrelinhas o risco de, dada a fragilidade dos elos produtivos, políticas de incentivo à produção podem ter alcance limitado, e por consequência, estratégias de desenvolvimento econômico tornam-se mais difíceis de serem implantadas e implementadas.

RE\&D Econ. e Desenv., Santa Maria, vol. 29, n.1, p. 587 - 609, jan. - jul. 2017 


\section{Figura 4: Escola da UFRGS - Histórico-Institucionalista-Shumpeteriana}

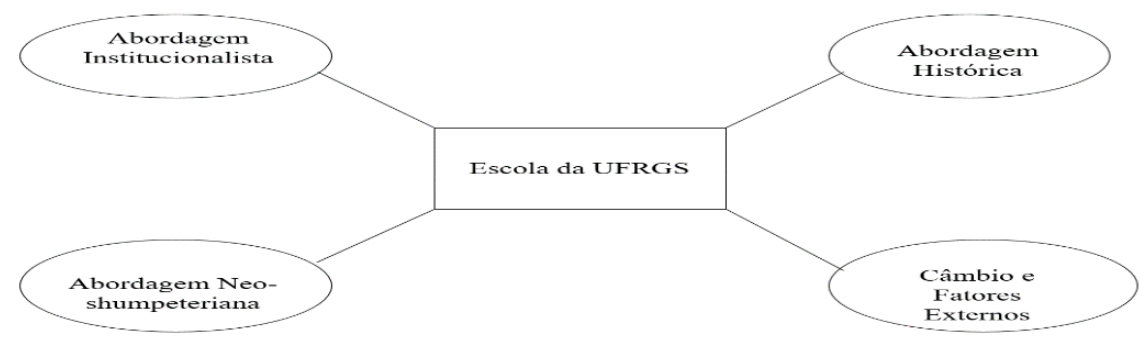

Fonte: Elaboração própria

Por fim, cabe ressaltar o estudo realizado por Schapiro (2013), em que por meio de elementos da economia institucional, o autor traça um panorama da atuação do Estado e os arranjos político-institucionais vigentes na prática de política industrial, em destaque o Plano Brasil Maior. Nesta perspectiva, a maior parte das ações do Estado brasileiro, apesar de terem em vista a transformação industrial, tem se caracterizado por viés corretivo ao contrário de um viés transformador. As razões decorrem, em grande medida, das debilidades institucionais verificadas tanto nas dimensões técnico-administrativa e política, como na dificuldade de coordenar esforços entre setor privado e o setor público, gerando o que se pode chamar de cacofonia decisória, ou seja, uma política industrial oca com representantes de diversos ministérios, mas sem centralidade decisória formal e material (SCHAPIRO, 2013).

Desta forma, a Figura 4 sintetiza o pensamento desta escola de pensamento. Neste contexto, engloba formas de análise que vão além do uso de variáveis tradicionalmente alvo de política econômica. Resgata a dimensão histórica e a importância das decisões de estratégia de desenvolvimento como elemento importante para entender a quadro de desindustrialização atual e as possibilidades de sua superação. Além disso, a questão institucional é colocada em debate como um elemento importante para entender a forma como o Estado age, e suas limitações no processo de coordenação de ações que visem reverter o quadro de desindustrialização em curso. Tratam-se de elementos nem sempre quantificáveis e passiveis de ação deliberada de instrumental e política econômica e que na maioria das vezes exercem papel central no sucesso ou fracasso no sentido de agir em prol da indústria nacional.

\section{PROPOSTAS DE POLÍTICA ECONÔMICA E DE REVERSÃO DA DESINDUSTRIALIZAÇÃO}

\subsection{ESCOLA DA UNICAMP}

A escola de Campinas tem procurado estimular o debate, e a sistematização do modelo de política econômica denominado "Social Desenvolvimentista" como forma de reversão da desindustrialização e estímulo à economia brasileira. Este, trata-se de um modelo em que as políticas de redistribuição de renda e de aumento real do salário mínimo, aliado a uma forte expansão do crédito bancário, são responsáveis por estimular o

RE\&D Econ. e Desenv., Santa Maria, vol. 29, n.1, p. 587 - 609, jan. - jul. 2017 
crescimento dos gastos de consumo, o que conduz os empresários a promoverem investimento, e por sua vez ao aumento simultâneo da capacidade produtiva e da produtividade do trabalho (OREIRO, 2013). Para Bielschowsky (2001, apud Carneiro, 2012), trata-se de uma estratégia de crescimento baseada na ampliação e generalização do consumo de massa. Estudos consideram que o Social Desenvolvimentismo, de origem nos anos de 2002/2003, é colocado em prática com intensidade pós 2005 , se assemelhando ao regime wage-led (BASTOS, 2012; MELLO, 2009).

Entretanto, a viabilidade deste regime tem sido questionada, dado que no longo prazo torna-se insustentável a sistemática flexibilização fiscal e ampliação das políticas sociais com crescimento do salário real acima da produtividade como a variável condutora do processo de crescimento econômico (BASTOS, 2012). Em postura crítica, Oreiro (2014) chama esta política econômica de um trade-off entre competitividade externa e estabilidade da taxa de inflação, vindo a denominar o referido regime como "desenvolvimentismo inconsistente".

\subsection{ESCOLA DA FGV-SP}

A Escola da FGV-SP, por meio dos trabalhos de Bresser-Pereira $(2010,2011,2012)$, propõe como solução o "Novo Desenvolvimentismo", que é definido como um conjunto de propostas de reformas institucionais e de políticas econômicas, por meio das quais as nações de desenvolvimento médio buscam alcançar o nível de renda per capita dos países desenvolvidos, sendo que para tanto, a estratégia para alcançar este objetivo baseia-se na adoção de um regime de crescimento do tipo export-led (OREIRO, 2012).

Nesse sentido, faz-se necessário uma política cambial ativa, mantendo a taxa de câmbio em níveis competitivos no médio e longo prazo, bem como uma política salarial que promova a moderação salarial, ao vincular o aumento dos salários reais ao crescimento da produtividade do trabalho. Nestes termos, uma taxa de câmbio competitiva estimula os investimentos orientados para a exportação, e aumenta correspondentemente a poupança interna. Assim, quando o nível da taxa de câmbio corresponde ao "equilíbrio industrial", toda demanda externa é aberta para as empresas efetivamente competentes (BRESSER e GALA, 2010).

\subsection{ESCOLA DA PUC/RJ- CASA DAS GARÇAS}

Esta escola de pensamento tem apontado a necessidade do Brasil promover uma série de reformas econômicas pró-mercado. Bacha e De Bolle (2013) apontam que o essencial na discussão sobre a economia brasileira, não seria a questão da desindustrialização em si, mas sim, a necessidade de concentrar esforços no sentido de reconfigurar a estrutura econômica brasileira, objetivando ampliar a abertura econômica, com integração da indústria nacional aos mercados globais e suas cadeias de valor. Uma solução reside na adoção de uma política de integração gradual às cadeias globais de valor por meio da ampliação do número de Assinaturas de Acordos de Preferência Comerciais (APCs). Além disso, propõem a reforma fiscal, e substituição de tarifas por câmbio visando reverter a sequência de "Pibinhos", o que permitiria ao país fugir da armadilha de renda média (BACHA, 2013).

RE\&D Econ. e Desenv., Santa Maria, vol. 29, n.1, p. 587 - 609, jan. - jul. 2017 


\subsection{ESCOLA DA UFRGS}

Apesar de ainda incipiente, é possível traçar alguns elementos que configuram um esboço de proposta de ações e políticas de reversão do quadro de desindustrialização em curso na economia brasileira. Cunha, Lelis e Bichara, (2012); Cunha, Lelis e Fligenspan (2013) apontam para a necessidade de políticas industriais mais robustas, com foco na inovação tecnológica e ampliação dos coeficientes de exportação, associada à modernização da infraestrutura e redução das distorções macroeconômicas, tais como as causadas pelas taxas de câmbio e juros, consideradas inapropriadas para a indústria nacional.

Por fim, a palavra síntese desta escola de pensamento pode ser compreendida em Arend (2009) e Arend e Fonseca (2012), e se trata da necessidade do Brasil desenvolver uma Estratégia Nacional de Desenvolvimento. Esta estratégia considera o desenvolvimentismo como elemento importante para construir o "interesse nacional", visto como um conjunto de valores que da mesma forma como nos governos dos países líderes, existe a consciência dos limites do capital externo como impulsionador do desenvolvimento no longo prazo (AREND, 2009).

Um sumário sobre as propostas de política de desenvolvimento, e reversão da situação atual em que se encontra a indústria nacional pode ser observado pelo Quadro 1.

Quadro 1 - Síntese das propostas de política por escola de pensamento.

\begin{tabular}{|c|c|}
\hline $\begin{array}{l}\text { Escola de Campinas } \\
\text { - } \quad \text { Wage-led / Social Desenvolvimento } \\
\text { - } \quad \text { Distribuição de renda; } \\
\text { - } \quad \text { Aumento real do salário mínimo; } \\
\text { - } \quad \text { Expansão do crédito; } \\
\text { - }\end{array}$ & $\begin{array}{l}\text { Escola da PUC/RJ - Casa das Garcas } \\
\text { - } \\
\text { - } \\
\text { - } \\
\text { - Intoformas Pró-mercado: } \\
\text { valora a abertura gradual às conômica; } \\
\text { - } \quad \text { Reforma fiscal; }\end{array}$ \\
\hline \begin{tabular}{ll}
\multicolumn{1}{c}{ Escola da FGV } \\
- & Export-led / Novo Desenvolviment: \\
- & Política Cambial ativa e competitiva; \\
- & Política salarial compatível com a \\
& produtividade;
\end{tabular} & $\begin{array}{l}\text { Escola da UFRGS } \\
\text { - } \quad \text { Redesenho institucional pró-política } \\
\text { industrial; } \\
\text { - } \quad \text { Estratégia nacional de desenvolvimentode } \\
\text { longo prazo; } \\
\text { - } \quad \text { Foco em Inovação; }\end{array}$ \\
\hline
\end{tabular}

Fonte: Elaboração própria

\section{CONCLUSÃO}

O debate sobre a desindustrialização tem sido intenso e amplo, conformando uma matriz de pensamento capaz de entender o problema da indústria nacional em várias dimensões. Do ponto de vista da Escola de Campinas, as causas da desindustrialização brasileira residem na forma de condução da política econômica após meados da década de 80. A adoção do neo-liberalismo como forma de condução da política econômica e o enfraquecimento do Estado é central para entender o processo de deterioração da estrutura produtiva em um momento em que a economia mundial passava por um processo de mudança do paradigma produtivo.

A Escola da FGV-SP apesar de reconhecer em parte os determinantes da desindustrialização apontados pela Escola de Campinas, considera o câmbio como central

RE\&D Econ. e Desenv., Santa Maria, vol. 29, n.1, p. 587 - 609, jan. - jul. 2017 
para entender o agravamento do processo de desindustrialização da economia brasileira. A concepção de uma taxa de câmbio ótima para a indústria é o elemento central e condição sine qua non para a formulação de uma política industrial capaz de reverter o quadro de "doença holandesa" por que passa o Brasil.

A Escola da PUC/RJ -Casa das Garças apresenta uma visão mais ortodoxa, e considera que apesar de estar havendo um processo de desindustrialização em curso, esta trata-se de um comportamento natural, em função do passado brasileiro ser marcado pelo excesso de industrialização. Ponto de destaque desta Escola é a necessidade de menor intervenção Estatal no que se refere a política econômica, e a importância do mercado como elemento essencial para reativar a industrial e a economia brasileira.

Por fim, as interpretações da Escola da UFRGS transcendem a dimensão meramente econômica, ao considerar essencial não só a história, mas também as instituições como elementos decisivos para entender os avanços e retrocessos em termos de política econômica. Estas abordagens avançam na compreensão da trajetória industrial brasileira ao considerar aspectos muitas vezes não imediatamente visíveis, mas que em grande medida são determinantes na elaboração da estratégia nacional de desenvolvimento.

\section{REFERÊNCIAS BIBLIOGRÁFICAS}

AREND, M. 50 anos de industrialização do Brasil (1955-2005): uma análise evolucionária. 2009. 251 f. Tese (Doutorado em Economia) - Universidade Federal do Rio Grande do Sul, Porto Alegre, 2009.

AREND, Marcelo. A industrialização do Brasil ante a nova divisão internacional do trabalho. Texto para Discussão, Instituto de Pesquisa Econômica Aplicada (IPEA), 2015. Disponível em: <http://repositorio.ipea.gov.br/bitstream/11058/4620/1/td_2105.pdf>. Acesso em: 20 agosto 2015.

AREND, M.; FONSECA, P. C. D. Brasil (1955-2005): 25 anos de catching up, 25 anos de falling behind. Revista de Economia Política, v. 32, n. 1, p. 33-54, 2012. Disponível em: <http://www.scielo.br/pdf/rep/v32n1/03.pdf >. Acesso em: 23 março 2015.

BASTOS, P. P. Z. A economia política do novo-desenvolvimentismo e do social desenvolvimentismo. Economia e Sociedade, v. 21, n. especial, p. 779-810, 2012. Disponível em: <http://www.scielo.br/pdf/ecos/v21nspe/v21nspea04.pdf >. Acesso em: 15 agosto 2015.

BACHA, E. L.; DE BOLLE, M. B. O futuro da indústria no Brasil: desindustrialização em debate. Rio de Janeiro: Civilização Brasileira, 2013.

BACHA, E. L.; BONELLI, R. Uma interpretação das causas da desaceleração econômica do Brasil. Revista de economia política, v. 25, n. 3, p. 163-189, 2005. Disponível em: < http://www.scielo.br/pdf/rep/v25n3/a01v25n3.pdf>. Acesso em:15 agosto 2015 .

BARROS, O.; PEREIRA, R. R. Desmistificando a tese de desindustrialização: reestruturação da indústria brasileira em uma época de transformações globais. In:

RE\&D Econ. e Desenv., Santa Maria, vol. 29, n.1, p. 587 - 609, jan. - jul. 2017 
BARROS, O.; GIAMBIAGI, F. (Org.). Brasil globalizado: o Brasil em um mundo surpreendente. Rio de Janeiro: Elsevier, 2008, p. 299-330.

BERRIEL, T.; BONOMO, M.; CARVALHO, C. Diversificação da economia e desindustrialização. In: BACHA, E.; BALLE, M. B. (orgs.) O futuro da indústria no Brasil: desindustrialização em debate. Rio de Janeiro: Civilização Brasileira, 2013, p.315330.

BIELSCHOWSKY, R. Anotações sobre a estratégia de crescimento pelo mercado interno de consumo popular e o programa do PT para 2003-2006. São Paulo: Instituto da Cidadania, 2001.

BONELLI, R.; PINHEIRO, A. C. Competitividade e desempenho industrial: mais que só câmbio. In: XXIV FÓRUM NACIONAL RUMO AO BRASIL DESENVOLVIDO, 2012, Rio de Janeiro. Estudos e Pesquisas... Rio de Janeiro: INAE, 2012. Disponível em: $<$ http://www.inae.org.br/estudo/competitividade-e-desempenho-industrial-mais-que-so-ocambio/>. Acesso em:15 agosto 2015.

BONELLI, R.; PESSÔA, S. A. Desindustrialização no Brasil: um resumo da evidência. Rio de Janeiro: Instituto Brasileiro de Economia / FGV (Texto para discussão n. 7), 2010. Disponível em: $<$ http://bibliotecadigital.fgv.br/dspace/bitstream/handle/10438/11689/Desindustrializa\%E 7\%E3o\%20no\%20Brasil.pdf?sequence=1>. Acesso em:10 abril 2015.

BONELLI, R.; PESSOA, S. A.; MATOS, S. Desindustrialização no Brasil: fatos e interpretação. In: BACHA, E.; BALLE, M. B. (orgs.) O futuro da indústria no Brasil: desindustrialização em debate. Rio de Janeiro: Civilização Brasileira, 2013, p. 201-225.

BRESSER-PEREIRA, L. C. Maldição dos recursos naturais. Folha de S. Paulo, São Paulo, 06 jun. 2005. Folha Mercado, Opinião Econômica. Disponível em: $<$ http://www1.folha.uol.com.br/fsp/dinheiro/fi0606200505.htm >. Acesso em: 05 junho 2015.

BRESSER-PEREIRA, L. C. Uma escola de pensamento keynesiano-estruturalista no Brasil? Revista de Economia Política, v. 31, nº 2, p. 305-314, 2011. Disponível em: < http://www.scielo.br/pdf/rep/v31n2/08.pdf>. Acesso em: 07 março 2015.

BRESSER-PEREIRA, L. C. The value of the exchange rate and the Dutch disease. Revista de Economia Política, v. 33, n. 3, p. 371-387, 2013. Disponível em: $<$ http://www.scielo.br/pdf/rep/v33n3/v33n3a01.pdf >. Acesso em: 07 março 2015.

BRESSER-PEREIRA, L. C.; GALA, P. Crítica do crescimento com poupança externa. São Paulo: Ede Economia de São Paulo / FGV, (Texto para Discussão n. 145), $2005 . \quad$ Disponível em:

$<$ http://gvpesquisa.fgv.br/sites/gvpesquisa.fgv.br/files/arquivos/bresser__criticacrescpoupancaweb.pdf>. Acesso em: 07 março 2015.

BRESSER-PEREIRA， L. C.; GALA， P. Macroeconomia estruturalista do desenvolvimento. Revista de Economia Política, v. 30, n. 4, p. 663-686, 2010. Disponível em: < http://www.scielo.br/pdf/rep/v30n4/v30n4a07.pdf > . Acesso em: 09 março 2015.

RE\&D Econ. e Desenv., Santa Maria, vol. 29, n.1, p. 587 - 609, jan. - jul. 2017 
BRESSER-PEREIRA, L. C.; MARCONI, N. Existe Doença Holandesa no Brasil? In: IV FÓRUM DE ECONOMIA DA FUNDAÇÃO GETÚLIO VARGAS, 2008, São Paulo. Trabalho Apresentado... São Paulo: FGV, 2008. Disponível em: $<$ http://www.bresserpereira.org.br/papers/2008/08.14.Existe.doen\%C3\%A7a.holandesa.c omNelson.Marconi.5.4.08.pdf>. Acesso em: 09 março 2015.

BRESSER-PEREIRA, L. C.; MARCONI, N. Doença holandesa e desindustrialização. Valor Econômico, São Paulo, 25 nov. 2009. Caderno Mercado. Disponível em: $<$ http://www.bresserpereira.org.br/Articles/2009/09.11.25.Doenca_holandesa_e_desindus trializacao.pdf > . Acesso em: 10 março 2015.

BRESSER-PEREIRA, L. C.; MARCONI, N.; OREIRO, J. L. A doença holandesa. Globalização e competição: por que alguns países emergentes têm sucesso e outros não. Rio de Janeiro: Elsevier, p. 141-171, 2009.

BRESSER-PEREIRA, L. C.; MARCONI, N.; OREIRO, J. L. A theoretical framework for a structuralist development macroeconomics. São Paulo: Escola de Economia de São Paulo / FGV (texto para discussão n. 317), 2012. Disponível em: $<$ http://www.bresserpereira.org.br/papers/2014/377-Theoretical-Framework-MarconiOreiro-Ch.4.pdf>. Acesso em: 03 maio 2015.

BRESSER-PEREIRA, L. C.; NAKANO, Y. Crescimento econômico com poupança externa? Revista de economia política, v. 23, n. 2, p. 3-27, 2003. Disponível em: $<$ http://www.rep.org.br/pdf/90-1.pdf>. Acesso em: 06 maio 2015.

CAMPOLINA DINIZ, C.; CAMPOLINA, B. A região metropolitana de São Paulo: reestruturação, re-espacialização e novas funções. Revista EURE, v. 33, n. 98, p. 27-43, 2007. Disponível em: <http://www.scielo.cl/pdf/eure/v33n98/art02.pdf>. Acesso em: 03 novembro 2015.

CANO, W. Industrialização, desindustrialização e políticas de desenvolvimento. Revista Faac, v. 1, n. 2, p. 155-164, 2011. Disponível em: $<$ http://www2.faac.unesp.br/revistafaac/index.php/revista/article/view/65/27>. Acesso em: 10 setembro 2015.

CANO, W. A desindustrialização no Brasil. Campinas: Instituto de Economia/Unicamp, (Texto para discussão n. 200), 2012.

CANO, W. Industrialização e (sub) desenvolvimento. Campinas: Instituto de Economia/Unicamp, (Texto para discussão n. 244), 2014. Disponível em: $<\mathrm{http}$ ://www.eco.unicamp.br/docprod/downarq.php?id=3368\&tp=a>. Acesso em: 28 junho 2015.

CARNEIRO, R. Desenvolvimento em crise: a economia brasileira no último quarto do século XX. São Paulo: Unesp, 2002.

RE\&D Econ. e Desenv., Santa Maria, vol. 29, n.1, p. 587 - 609, jan. - jul. 2017 
CARNEIRO, R. M. Dinâmica de crescimento da economia brasileira: uma visão de longo prazo. Campinas: Instituto de Economia/Unicamp (Texto para Discussão, n. 130), 2007.

CARNEIRO, R. M. Impasses do desenvolvimento brasileiro: a questão produtiva. Campinas: Instituto de Economia/Unicamp (Textos para Discussão n. 153), 2008.

CARNEIRO, R. M. Velhos e novos desenvolvimentismos. Economia e Sociedade, v. 21, $\mathrm{n}^{\circ}$. esp., p. 749-778, 2012. Disponível em: $<$ http://www3.eco.unicamp.br/cecon/images/arquivos/3232.pdf $>$. Acesso em: 09 julho 2015 .

CARNEIRO, R. M. Crise, ajustamento e estagnação, a economia brasileira do período de 1974-89. Economia e Sociedade, v. 2, no. 1, p. 145-169, 2016. Disponível em: $<$ http://periodicos.sbu.unicamp.br/ojs/index.php/ecos/article/view/8643302>. Acesso em: 10 julho 2015.

COMIN, A. A desindustrialização truncada: perspectivas do desenvolvimento econômico brasileiro. 2009. 257 f. Tese (Doutorado em Ciências Econômicas) - Instituto de Economia, Unicamp, Campinas, 2009.

COUTINHO, L. A especialização regressiva: um balanço do desempenho industrial pósestabilização. In: VELLOSO, J. P. R (coord.) et. al. Brasil: desafios de um país em transformação. Rio de Janeiro: José Olympio, 1997, p. 84-115.

CUNHA, A. M.; LÉLIS, M. T. C.; BICHARA, J. S. Brazil as a mirror of China: new trends after the global financial crisis. Revista de Economia Contemporânea, v. 16, $\mathrm{n}^{\circ} .2$, p. 208-236, 2012. Disponível em: <http://www.scielo.br/pdf/rec/v16n2/a03v16n2.pdf>. Acesso em: 20 maio 2015.

CUNHA, A. M.; LÉLIS, M. T. C.; FLIGENSPAN, F. B. Desindustrialização e comércio exterior: evidências recentes para o Brasil. Revista de Economia Política, v. 33, n .3 , p. 463-485, 2013. Disponível em: <http://www.scielo.br/pdf/rep/v33n3/v33n3a06.pdf>. Acesso em: 02 julho 2015.

DA ROCHA LOURES, R. C.; OREIRO, J. L.; PASSOS, C. A. K. Desindustrialização: a crônica da servidão consentida. Economia \& Tecnologia, 2006.

FEIJÓ, C. A.; CARVALHO, P. G. M; ALMEIDA, J. S. G. Ocorreu uma desindustrialização no Brasil. São Paulo: IEDI, 2005. Disponível em: $<$ http://www.iedi.org.br/admin_ori/pdf/20051129_desindustrializacao.pdf $>$. Acesso em: 15 março 2015.

FEIJÓ, C. A.; OLIVEIRA, D. Mudanças estruturais na economia brasileira e seus impactos sobre a evolução da produtividade na indústria de transformação pós- 1990. In: AZEVEDO, A. F.; FEIJÓ, C. A.; CORONEL, D. A. (orgs.). A desindustrialização brasileira. São Leopoldo: Editora Unisinos, 2013, p. 221-248.

FERRAZ, J. C.; KUPFER, D.; HAGUENAUER, L. Made in Brazil: desafios competitivos para a indústria. Rio de janeiro: Campus, 1995.

RE\&D Econ. e Desenv., Santa Maria, vol. 29, n.1, p. 587 - 609, jan. - jul. 2017 
FISHLOWFISHLOW, A. Origens e consequências da substituição de importações: 40 anos depois. In: BACHA, E.; BALLE, M. B. (orgs.) O futuro da indústria no Brasil: desindustrialização em debate. Rio de Janeiro: Civilização Brasileira, 2013, p. 23-44.

FURTADO, C. Desenvolvimento e subdesenvolvimento. Rio de Janeiro: Fundo de Cultura, 1961.

KALDOR, N. Causes of the slow rate of economic growth of the United Kingdom. London: Cambridge University Press, 1966.

LAMONICA, M. T.; FEIJÓ, C. A. Mudança da estrutura industrial e desenvolvimento econômico: as lições de Kaldor para a indústria brasileira. Rio de Janeiro: Universidade Federal Fluminense. (Texto para discussão n. 265), 2010. Disponível em: $<$ http://www.uff.br/econ/download/tds/UFF_TD265.pdf $>$. Acesso em: 10 julho 2015.

LAPLANE, M.; SARTI, F. Prometeu Acorrentado: o Brasil na indústria mundial no início do século XXI. Política Econômica em Foco, n. 7, nov.2005/abr.2006, p. 271-291, 2006. Disponível em: <http://www3.eco.unicamp.br/cecon/images/arquivos/pesquisa2003-2006/Secao_IX07PEF.pdf>. Acesso em: 20 maio 2015.

LAZZARINI, S. G.; JANK, M. S.; INOUE, C. F. K. Commodities no Brasil: maldição ou bênção. In: BACHA, E.; BALLE, M. B. (orgs.) O futuro da indústria no Brasil: desindustrialização em debate. Rio de Janeiro: Civilização Brasileira, 2013, p. 201-225.

MALAN, P. Prefácio. In: BACHA, E.; BALLE, M. B. (orgs.) O futuro da indústria no Brasil: desindustrialização em debate. Rio de Janeiro: Civilização Brasileira, 2013, p. 711.

DE MELLO, E. B. A nova política externa independente: o Governo Lula e a inserção externa brasileira no século XXI. 2009. 253 p. (Tese de Doutorado) - Programa de PósGraduação em Economia, Universidade Federal do Rio Grande do Sul. 2009.

NASSIF, A.; FEIJÓ, C.; ARAÚJO, E. O debate sobre a desindustrialização precoce no Brasil: estamos avançando ou regredindo em relação aos países desenvolvidos. In: AZEVEDO, A. F. Z.; FEIJÓ, C.; CORONEL, D. A. (coords.) A desindustrialização brasileira. São Leopoldo: Editora Unisinos, 2013, p. 25-70.

OOREIRO, J. L. C. Novo-desenvolvimentismo, crescimento econômico e regimes de política macroeconômica. Estudos Avançados/USP, v. 26, n. 75, p. 29-40, 2012. Disponível em: <http://www.revistas.usp.br/eav/article/view/39482/42366>. Acesso em:11 julho 2015 .

OREIRO, J. L. C.; FEIJÓ, C. A. Desindustrialização: conceituação, causas, efeitos e o caso brasileiro. Revista de economia política, v. 30, n. 2, p. 219-232, 2010. Disponível em: $<$ http://www.scielo.br/pdf/rep/v30n2/03.pdf>. Acesso em: 13 maio 2015.

OREIRO, J. L. C. Novo-desenvolvimentismo, crescimento econômico e regimes de política macroeconômica. Estudos avançados, v. 26, n. 75, p. 29-40, 2012. Disponível em: $<$ http://www.scielo.br/pdf/ea/v26n75/03.pdf>. Acesso em:16 março 2015

OREIRO, J. L. C. Muito Além do Tripé: proposta de um novo regime de política macroeconômica para dobrar a renda per-capita em 20 anos. In: SEMINÁRIO INDÚSTRIA E DESENVOLVIMENTO PRODUTIVO DO BRASIL, 2014, São Paulo.

RE\&D Econ. e Desenv., Santa Maria, vol. 29, n.1, p. 587 - 609, jan. - jul. 2017 
Artigo... São Paulo: Escola de Economia de São Paulo/FGV, 2014. Disponível em: $<$ http://joseluisoreiro.com.br/site/link/4a8b75db94b90c13b7e337fdbeacf4a283989497.pd f>. Acesso em: 25 abril 2015.

OREIRO, J. L. C. Desenvolvimentismo sem consistência. Valor Econômico, São Paulo, 18 jun. 2013. Caderno Opinião. Disponível em: $<$ http://www.valor.com.br/opiniao/3164976/ desenvolvimentismo-sem-consistencia >. Acesso em:16 seembro 2015.

PALMA, J. G. Quatro fontes de "desindustrialização" e um novo conceito de "doença holandesa". In: CONFERÊNCIA DE INDUSTRIALIZAÇÃO, DESINDUSTRIALIZAÇÃO E DESENVOLVIMENTO, 2005, São Paulo. Trabalho Apresentado... São Paulo: FIESP / IEDI, 2005. Disponível em: $<$ https://macrododesenvolvimento.files.wordpress.com/2013/06/52020quatro20fontes20_2_.pdf>. Acesso em: 01 julho 2015.

PALMA, J. G. "De-industrialization", "premature" de-industrialization and the Dutch Disease. In: DURLAUF, S. N.; BLUME, L. E. (org.) The new palgrave dictionary of economics. $2^{\circ}$ ed., United Kingdom: Palgrave Macmillan, 2008.

PASTORE, A.; GAZZANO, M.; PINOTTI. Por que a produção industrial não cresce desde 2010. In: BACHA, E.; BALLE, M. B. (orgs.) O futuro da indústria no Brasil: desindustrialização em debate. Rio de Janeiro: Civilização Brasileira, 2013, p. 121- 156.

PÉREZ, C. Revoluciones tecnológicas y capital financiero: la dinámica de las grandes burbujas financieras y las épocas de bonanza. México: Siglo XXI, 2004.

PESSOTI, B. C; PESSOTI, G. C. A indissociável relação entre indústria, desenvolvimento econômico e políticas indústrias no Brasil. Revista de Desenvolvimento Econômico, v. 11, n. 19, p. 27-44, 2009. Disponível em: $<$ http://www.revistas.unifacs.br/index.php/rde/article/view/1051/829>. Acesso em: 25 abril 2015.

PRATES, D. M. A inserção externa da economia brasileira no governo Lula. Política Econômica em Foco, n. 7, seção IV, nov.2005/abr.2006. Disponível em: <www.eco.unicamp.br/docprod/downarq.php?id=215\&tp=a>. Acesso em: 27 maio 2015.

PUGA, F. P. Aumento das importações não gerou desindustrialização. Brasília: BNDES / Visão do Desenvolvimento, n. 26, 2007. Disponível em: $<$ http://www.bndes.gov.br/Site

BNDES/export/sites/default/bndes_pt/Galerias/Arquivos/conhecimento/visao/visao_26.p df $>$. Acesso em: 27 março 2015.

ROWTHORN, R.; COUTTS, K. Commentary: De-industrialisation and the balance of payments in advanced economies. Cambridge Journal of Economics. v. 28, n. 5, p. 767$790,2004$.

RROWTHORN, R.; RAMASWAMY, R. Deindustrialization: causes and implications. International Monetary Fund, 1997, p. 7-22. Disponível em: $<$ https://www.imf.org/external/ pubs/ft/wp/wp9742.pdf>. Acesso em: 02 junho 2015.

RE\&D Econ. e Desenv., Santa Maria, vol. 29, n.1, p. 587 - 609, jan. - jul. 2017 
ROWTHORN, R.; RAMASWAMY, R. Growth, trade, and deindustrialization. International Monetary Fund, 1999, p. 18-34. Disponível em: $<$ https://www.imf.org/external/pubs/ft/wp/wp9860.pdf>. Acesso em: 12 julho 2015.

SAMPAIO, D. P, Desindustrialização e estruturas produtivas regionais no Brasil. 2015. 256 f. (Tese de Doutorado) - Programa de Pós-Graduação em Economia, Instituto de Economia, Universidade Estadual de Campinas, Campinas, 2015.

SARTI, F.; HIRATUKA, C. Desenvolvimento industrial no Brasil: oportunidades e desafios futuros. Campinas: Instituto de Economia/Unicamp, (Texto para discussão n. 187), 2011.

SCHAPIRO, M. G. Ativismo estatal e industrialismo defensivo: instrumentos e capacidades na política industrial brasileira. Rio de janeiro: Instituto de Pesquisa Econômica Aplicada (Texto para discussão), 2013. Disponível em: $<$ http://repositorio.ipea.gov.br/bitstream/ 11058/ 2922/1/TD_1856.pdf>. Acesso em: 16 abril 2015.

SILVA, H. C. O processo de desindustrialização: Uma avaliação sob a perspectiva da economia brasileira (1990-2010). 2012. 155 p. Dissertação (Mestrado em Economia), Programa de Pós-Graduação em Economia, Universidade Federal de Santa Catarina, Florianópolis. 2012.

SOARES, C.; TEIXEIRA, A; OREIRO, J. L. Uma Análise Empírica dos Determinantes da Desindustrialização no Caso Brasileiro. In: AZEVEDO, A. F.; FEIJÓ, C. A.; CORONEL, D. A. (orgs.). A desindustrialização brasileira. São Leopoldo: Ed. Unisinos, 2013, p. 105-145.

SONAGLIO, C. M. Evidências de desindustrialização no Brasil: uma análise com dados em painel. In: AZEVEDO, A. F.; FEIJÓ, C. A.; CORONEL, D. A. (orgs.). A desindustrialização Brasileira. São Leopoldo: Editora Unisinos, 2013, p. 71-104.

SOUZA, N. J. Desenvolvimento econômico. $4^{\circ}$. ed. São Paulo: Editora Atlas, 1999, p. 242-243. 1999.

THIRWALL, A. P. The nature of economic growth: an alternative framework for understanding the performance of nations. Northampton: Edward Elgar. 2002.

TTREGENNA, F. Characterising deindustrialisation: an analysis of changes in manufacturing employment and output internationally. Cambridge Journal of Economics, v. 33, n. 3, p. 433-466, 2009.

UNCTAD. World Development Report. Genebra, 2003. Disponível em: < http://unctad.org/en/Docs/tdr2003_en.pdf>. Acesso em: 11 agosto 2015.

UNIDO. Industrial Development Report. Vienna: UNIDO, 2013. Disponível em: $<$ www.unido.org>. Acesso em: 11 agosto 2015.

RE\&D Econ. e Desenv., Santa Maria, vol. 29, n.1, p. 587 - 609, jan. - jul. 2017 